\title{
The Influence of Translation Techniques on the Accuracy and Acceptability of Translated Utterances that Flout the Maxim of Quality
}

\author{
Ria Aresta; M.R Nababan; Djatmika \\ Sebelas Maret University, Surakarta, Indonesia \\ E-mail: aresta.ria1515@gmail.com
}

\begin{abstract}
Translating the implied meanings in utterances is one of the trickiest situations translators may confront. One example is in translating utterances that flout the maxim of quality. When a speaker flouts the maxim of quality, they are implying further information that is not represented in the utterance. Translators use various translation techniques in order to convey the meaning of the original text in the most appropriate and acceptable form in the target text. This study investigates how translation techniques may affect the quality of a translation. The approach implemented in this study is pragmatics in translation. This study belongs to the field of descriptive qualitative research with an embedded case study. For data, we look at all the utterances which may be said to be flouting the maxim of quality in the source text and its translation. Content analysis and focus group discussion were applied as the methods to collect and analyze the data. A focus group discussion was used to assess translation quality. The majority of the data was classified as accurate and acceptable, while the rest was considered less accurate and inaccurate due to the application of the translation technique amplification (addition), discursive creation and literal translation. Some data was also found to be less acceptable due to literal translation and pure borrowing.
\end{abstract}

Keywords: translation; flouting maxim; translation technique; translation accuracy; translation acceptability

\section{INTRODUCTION}

Translation is the process of transferring a written text from a source language to a target language (Hatim and Munday, 2004). It covers all dimensions of the source text, including linguistic organization, culture, intentions, feelings, style and time and should reproduce the entire text naturally, smoothly and as close to the original as possible in the target text (Zhonggang, 2006). Therefore, it is essential for translators to translate the source text into the target text as close as possible to what the author intends to convey, without changing the characteristics or the style of the original text. However, it is often difficult for the literary translator to preserve the meaning and the writing style unchanged, due to the differences between the two languages (ibid).
Translating the implied meanings of the utterances between two speakers can be regarded as one of the most difficult situations that translators may confront because understanding utterances is not simply a matter of knowing the meaning of the words uttered (Abdellah, 2004). Implicature is one of the complicating factors. Implicature is an additional conveyed meaning - when a speaker hints, suggests or conveys some meaning indirectly by means of language (Thomas, 1996). Basically, one process whereby an implicature is generated is the flouting of a maxim (Black, 2006). When someone is flouting a maxim, they are not deliberately trying to deceive or mislead their interlocutors, but they are deliberately not observing the maxims, in order 
for their interlocutors to understand another set of meaning (Paltridge, 2006).

Translating implicature is challenging work. The transfer of meaning is attached to the context of the situation and also linked to the source and target culture. The translator must also settle on what way $\mathrm{s} /$ he would translate the implicature; whether to retain the implicit meaning or make it more explicit (Sumardiono, 2010). In consequence, a translator must employ his/her knowledge of a variety of translation techniques in order to avoid a change of meaning in the translation process.

There are several previous studies related to the flouting of maxims within the cooperative principle from which this writer found research gaps. Faghih and Abbasi (2016) examined the translation techniques proposed by Molina and Albir (2002) and Newmark (1988) in translating the flouting of maxims in four short stories by Ernest Hemingway. Their study directs attention at specific translation techniques including linguistic amplification, linguistic compression, literal translation, transposition, established equivalent and free translation, while this study conducts the analysis based on the list of 18 techniques proposed by Molina and Albir (2002) as a system that is more explicit and concise. Further, Putri (2016) focuses her research on the translation techniques and translation quality on the utterances that accommodate the flouting of maxims in the novel The Cairo Affair (2014). Meanwhile, Nugraha (2016) investigates translation techniques and the translation quality of utterances that flout maxims in the subtitles of the movie The Queen (2006). Both of these pieces of research focus on all four maxims, while this study focuses only on one particular maxim, the maxim of quality. Putro and Iragiliati (2013) have conducted research on this one particular maxim alone. They studied the flouting of the quality maxim in baby milk slogans shown on TV advertisements, but their study did not investigate translation.

This study aims at (1) discovering the translation techniques applied in translating the utterances that appear to be flouting the maxim of quality in Tanti Lesmana's (2016) Indonesian translation of Jojo Moyes novel Me Before You (2012), and (2) describing the correlation between translation techniques and translation quality in terms of accuracy and acceptability.

Grice's theory of the "cooperative principle" holds that both speaker and listener have to approach a conversation with the purpose of avoiding misunderstanding (Grice, 1975). It means that conversational participants should hold a cooperative attitude. People have a successful conversation if they fulfill the cooperative principle, including its four subprinciples or maxims (Wijana \& Muhammad, 2011). The four maxims are the maxim of quantity, quality, relevance and manner (Grice, 1975). However, a speaker may disobey the cooperative principle. There are three ways in which the speaker disobeys it, namely: violating a maxim, flouting a maxim and opting out of a maxim (Birner, 2003). To flout a maxim is also to violate it, but in this case, the violation is so intentionally blatant that the hearer is expected to be aware of the violation (ibid).

In the case of the maxim of quality, the speakers are expected to be sincere and to say something that they believe corresponds to reality. They are assumed not to say anything that they believe to be false or anything for which they lack evidence (Cutting, 2012). To flout the maxim of quality, therefore, is to say something that does not represent what the speaker actually thinks or means. However, whenever a maxim is flouted, there must be an implicature to save the utterance from appearing to be a faulty contribution to a conversation (ibid). For example, when saying "I could eat a horse", the speaker flouts the maxim of quality using hyperbole. The speaker expects the listener to infer that $\mathrm{s} / \mathrm{he}$ is very hungry, instead of believing that $\mathrm{s} / \mathrm{he}$ could really eat a horse (Martin in Cutting 2003). There also other strategies where speakers flout the maxim of quality: using rhetorical questions, or using figures of speech such as irony, sarcasm, metaphor, etc... (Brown \& Levinson, 1987; Cutting, 2003; Birner, 2013).

The analysis in this study will be carried out using Molina and Albir's (2002) theory of translation techniques, as it allows the writer to clearly classify each piece of data studied. Newmark (1988) differentiates translation techniques from the translation method, stating that translation procedures or techniques are used for sentences while translation method is related to the whole text. For Molina and Albir (2002), translation techniques are a tool to analyze translation outcomes, describing how the target text functions related to corresponding units in the source text. They ensure that their techniques are both functional and dynamic in terms of (1) the genre of the text, (2) translation types (technical, literature etc...), (3) translation modes (written translation, sight translation etc...), (4) the purpose and characteristics of translation, and (5) the methods chosen (ibid). 
The 18 techniques that they propose are: adaptation, amplification, borrowing, calque, compensation, description, discursive creation, established equivalent, generalization, linguistic amplification, compression, literal translation, modulation, particularization, reduction, substitution, transposition, and variation.

A "high quality of translation" indicates a translation product that meets certain standards and criteria (Akhiroh, 2013). There are three criteria used for translation quality assessment: namely accuracy, acceptability and readability (Nababan, 2003). This study employed two criteria in evaluating translation quality: accuracy and acceptability. Accuracy relates to the precise understanding of the source language message and the transfer of the message as accurately as possible into the target language (Larson, 1998). This criterion covers the idea that good translation should completely convey the information contained in the source text. Larson (1984) says that a text is acceptable if it is expressed in the natural form of the target language. As part of a culture, language is regarded as acceptable if it accomplishes a natural expression (Nuraeni et al., 2016). Thus, it can be concluded that acceptability denotes a translated text being relevant and accepted by the reader. It is achieved by assessing what is culturally appropriate for the target audience and conveying that in the translation, whilst still maintaining the tone, context, and meaning of the original text.

This is descriptive, qualitative research with an embedded case study. Qualitative research is a research method in which the design or plan does not use statistical procedures (Sudaryanto, 1986). The research object of this study is the novel Me Before You by Jojo Moyes. The data used is all the utterances in the source text that flout the maxim of quality, and their translation. The data is collected using two methods; content analysis, and focus group discussion. This study employs Spradley's theory (1980) in analyzing the data. There are four major steps of analysis: domain analysis, taxonomic analysis, componential analysis and cultural theme analysis. The assessment of translation quality was obtained using a focus group of native Indonesian speakers who had a graduate level competence in English by conducting a focus group discussion with a questionnaire as a tool. The focus group evaluated the accuracy and acceptability of Tanti Lesmana's translation based on the theory of Nababan et al. (2012). They assessed the quality of the translation on a scale of 1 to 3 .

\section{FINDINGS AND DISCUSSION}

\section{Translation Techniques Used in Translating the Utterances Containing Flouting Maxim of Quality in Me Before You}

There are 139 utterances that flout the maxim of quality found in this text. There are 14 of Molina and Albir's translation techniques used by the translator in translating the utterances: established equivalent, amplification (explicitation), modulation, pure borrowing, implicitation, transposition, amplification (addition), reduction, generalization, literal translation, variation, discursive creation, particularization and description. Here, amplification is broken down into two categories: amplification explicitation, which elicits the meaning in the statement based on the context of the situation, and amplification addition which adds more information in the target text to help the reader in better understanding. The percentage of each translation technique is shown in table 1:

Table 1. The Classification of Translation Techniques Used to Translate the Utterances Containing Flouting Maxim of Quality in Me Before You

\begin{tabular}{|c|c|c|c|}
\hline No & $\begin{array}{l}\text { Translation } \\
\text { Technique }\end{array}$ & Total & $\begin{array}{c}\text { Percentage } \\
(\%)\end{array}$ \\
\hline 1 & $\begin{array}{l}\text { Established } \\
\text { equivalent }\end{array}$ & 454 & $62,62 \%$ \\
\hline 2 & Modulation & 80 & $11,04 \%$ \\
\hline 3 & $\begin{array}{l}\text { Amplification } \\
\text { (explicitation) }\end{array}$ & 69 & $9,52 \%$ \\
\hline 4 & Pure borrowing & 29 & $4 \%$ \\
\hline 5 & Implicitation & 24 & $3.31 \%$ \\
\hline 6 & Transposition & 17 & $2,34 \%$ \\
\hline 7 & $\begin{array}{c}\text { Amplification } \\
\text { (addition) }\end{array}$ & 11 & $1.52 \%$ \\
\hline 8 & Reduction & 11 & $1,52 \%$ \\
\hline 9 & Generalization & 7 & $0,96 \%$ \\
\hline 10 & Literal & 7 & $0,96 \%$ \\
\hline 11 & Variation & 6 & $0,83 \%$ \\
\hline 12 & Discursive creation & 4 & $0,55 \%$ \\
\hline 13 & Particularization & 4 & $0,55 \%$ \\
\hline 14 & Description & 2 & $0,28 \%$ \\
\hline \multicolumn{2}{|r|}{ Total } & 732 & $100 \%$ \\
\hline
\end{tabular}

Translation techniques are used for sentences and smaller units of language in a text (Newmark, 
1988). In line with this statement, Molina and Albir (2002) put forward the idea that that techniques have an impact at the level of the micro unit of text. Therefore, the identification process of translation techniques in this study is conducted at the micro level or at the smallest unit (word), subsequently, if a similar technique emerges several times in a single utterance, it is still counted. Established equivalent, amplification (explicitation) and modulation appear to be the most frequently used techniques. The employment of these techniques is shown as follows:

\section{Established Equivalent}

Established equivalent is a technique where a term or expression is translated using as an equivalent term of expression in the target language. This technique is the most dominant technique used in this study. Here is one use of established equivalent in this study:

\section{Source text}

Mrs. Traynor:

Mm... Your previous employer says you are a

"warm, chatty and life-enhancing presence."

Lou:

Yes, I paid him. (Moyes, 2012, p.22).

\section{Target text}

Mrs. Traynor:

Mm... Menurut mantan atasan anda, anda orang yang "hangat, suka mengobrol, dan membuat suasana ceria."

Lou:

Ya, saya membayarnya. (Moyes, 2016, p.43).

The conversation occurs in the middle of a job interview. Mrs. Traynor reads a positive reference from Lou's previous employer. Lou replies that she paid him to write a good reference for her. The statement counts as a flouting the maxim of quality. Mrs. Traynor is not expected to believe that Lou bribed anyone for the reference, just that she is making a joke in order to be friendly.

\section{Modulation}

Modulation is a translation technique that changes the point of view, focus or cognitive category in relation to the source text. It can be lexical or structural. The application of modulation technique is shown as follows:

\section{Source text}

Lou:

My favorite outfit was those glitter boots and my bumblebee tights.

Will:

Bumblebee tights? Black and yellow stripes.

Gorgeous. (Moyes, 2012, p.65)

Lou:

That's a bit hars.

\section{Target text}

Lou:

Perlengkapan favoritku adalah sepatu bot kerlap-kerlip itu dan celana kaus bumblebee-ku.

Will:

Celana kaus bumblebee? Garis-garis hitam dan kuning. Hebat. (Moyes, 2016, p.146).

Lou:

Komentarmu agak keterlaluan.

To keep him company, Will has asked Lou to stay a bit longer. Lou sings the Molahonkey song, a song her father used to sing when she was a kid. The song sounds ridiculous but keeps Will entertained. Will, then, asks Lou to tell him more about herself. Lou says something about her favorite outfit that her mother had given her when she was only three. She loved it so much that she wants to use it still at the age of 27. Will thinks that it is inappropriate for an adult to wear bumblebee tights, yet he states his opinion by saying the opposite using irony.

In the English original, the word gorgeous refers to the "appearance" of the bumblebee tights. However, the use of modulation technique in the Indonesian translation has changed the focus to Lou's behavior (wearing bumblebee tights in the same way a kid would).

\section{Amplification (Explicitation)}

Explicitation is a technique which introduces information from the source text that is implicit from the context or the situation. Here is one of the examples where the technique of explicitation is used:

\section{Source text}

Josephine:

She's a bright girl. She'll find herself something. 
She's got a solid employment record. Hasn't she? Frank will give her a good reference.

Bernard:

Oh, fecking marvelous... "Louisa Clark is very good at buttering toast and a dab hand with the old teapot.

Lou:

Thanks for the vote of confidence, Dad. (Moyes, 2012, p. 13).

\section{Target text}

Josephine:

Dia gadis yang cerdas. Dia pasti akan mendapatkan pekerjaan lain. Dia punya catatan kerja yang bagus, bukan? Frank akan memberikan referensi bagus untuknya.

Bernard:

Oh ya, bagus sekali... "Louisa Clark sangat mahir mengoleskan mentega pada roti, dan sangat cekatan menangani poci the tua."

Lou:

Terimakasih atas kevakinanmu, Dad. (Moyes, 2016, p. 23).

Lou has never worked anywhere but the cafe for the past six years. Now that the cafe is closed, she has to find a new job. Bernard is very concerned about it because he thinks no one would employ her since she does not have any job experiences or skills to put on her CV. Lou's utterance is considered to flout the maxim of quality: she does not really thank her father for the weak compliment.

\section{Pure Borrowing}

The fourth technique in the sequence is pure borrowing. This technique takes a word or expression straight from another language. In this study, borrowing is mostly used in translating names and places. Herman in Singgih (2014) says that translating names could be done in 4 ways; duplicate the name as it is in the source target (pure borrowing), change the pronunciation (naturalized borrowing), change the name into a word which has no relevance to the source text (adaptation), and translating the name by conveying the literal meaning (literal translation). Below, is one of the cases where the translator employs pure borrowing:

\section{Source text}

Lou:

Nathan? Are you still up for it?

Nathan:

You bet.

Lou:

And... Will?

Will:

Why not? I'm quite looking forward to seeing Clark throw herself into some rapids. (Moyes, 2012, p. 206).

\section{Target text}

Lou:

Nathan? Kau masih bersedia ikut?

Nathan:

Sudah pasti.

Lou:

Dan... Will?

Will:

Kenapa tidak? Aku penasaran ingin melihat Clark menerjunkan diri ke arus deras. (Moyes, 2016, p. 514).

In the exchange above, Lou makes sure that Nathan and Will still want to join her for the vacation. When Lou asks Will, he sarcastically says that he wants to see her throw herself into some rapids. Will actually implies a different interpretation. He thinks that Lou will not dare to do anything challenging out there.

\section{Implicitation}

Implicitation is in opposition to amplification. This technique belongs to reduction. It allows the situation to indicate information that is explicit in the source text.

\section{Source text}

Nathan:

Just to make sure she's all right. You know... I'm not sure if it's a good place for her to go alone. 
Will:

No. Very chivalrous of you, Nate.

Lou:

I think that is a very responsible thing to do. (Moyes, 2012, p. 222).

Will:

I have always admired Nathan for his selflessness. Especially when it comes to the fairer sex.

\section{Target text}

Nathan:

Sekedar memastikan dia aman-aman saja. Tahu kan... aku tidak yakin dia akan aman di sana, pergi sendirian.

Will:

Tentu. Kau memang sangat perhatian, Nate.

Lou:

Sangat bertanggungjawab. (Moyes, 2016, p. 553).

Will:

Sejak dulu aku mengagumi Nathan atas sifatnya yang tidak mementingkan dirinya sendiri. Terutama menyangkut cewek.

On the fourth night of their vacation, Nathan announces that he has a date and he has agreed to go down to the town with her. He says it is only to make sure that she will be okay down there. Both Will and Lou know Nathan so well that they lie about what they really think of Nathan and tease him by saying something in reverse. Here, the translator applied the implicitation technique in translating the utterance. We can see that the utterance is implicitly translated into an adjective phrase in the target text.

\section{Transposition}

Transposition is a technique which changes a grammatical category; the semantic elements are transferred to a grammatically different group of words.

\section{Source text}

Bernard:

Bernard Clark. Bernard. Sorry, um... I don't know how to greet a ... I can't shake your -

Will:

A curtsy will be fine. (Moyes, 2012, p. 125)
Bernard:

Hah! Yes. Curtsy. Nice one. Hah!

\section{Target text}

Bernard:

Bernard Clark. Bernard. Maaf, emm... Aku tidak tahu bagaimana mesti menyambut...aku tidak bisa menjabat -

Will:

Membungkuk manis saja. (Moyes, 2016, p. 229).

\section{Bernard:}

Hah! Ya. Membungkuk manis. Boleh juga. Hah!

Nathan has driven Will over to Lou's birthday. Bernard, Lou's father, greets them on the front porch. He reaches out his hand to shake Nathan's hand, then holds it out towards Will. He remembers that Will suffers from quadriplegia. Will asks for a curtsy as an alternative. In his statement, Will discreetly says that he does not need a formal greeting like shaking hand because he cannot move his hand. Mr. Bernard should understand that Will is just joking in asking for a curtsy.

The translator used the transposition technique, causing a grammatical unit shift when the noun phrase "a curtsy" in the source text is translated into the verb phrase "membungkuk manis" in the target text.

\section{Amplification (Addition)}

This technique is in opposition to the reduction technique. It is used to add more information that does not exist in the source text.

\section{Source text}

Wil:

Don't worry, it's only cashmere. (Moyes, 2012, p. 104)

\section{Target text}

Will:

Tidak apa-apa, toh bahannya cuma kasmir, kok. (Moyes, 2016, p. 243).

Lou and Nathan finally have managed to drag the chair towards the path but Will's blanket has half slipped off him and has somehow caught up in his wheels, leaving one corner torn and muddy. He stares at it for a moment and makes an ironic statement about it. Will is counted as flouting the maxim of quality by 
saying what is known to be false. Cashmere is a fine cloth, yet Will speaks as if it is not.

The translator employed the addition technique by adding the word "toh" and "kok" in the utterance to sustain the readability level of the translation.

\section{Reduction}

Reduction is a translation technique used to suppress a source text information item in the target text.

\section{Source text}

Nathan:

That's me done, Will. You want anything before I go?

Will:

No. Thank you, Nathan.

Nathan:

I'll leave you in Miss Clark's capable hands, then. See you at lunchtime, mate. (Moyes, 2012, p. 30).

\section{Target text}

Nathan:

Aku sudah selesai, Will. Ada yang kau inginkan sebelum aku pergi?

Will:

Tidak, terimakasih Nathan.

Nathan:

Kalau begitu, kau kupasrahkan ke tangan Miss Clark. Sampai ketemu waktu makan siang, Sobat. (Moyes, 2016, p. 64).

While heading out for lunch, Nathan demonstrates his relief by saying Will now is in Lou's capable hands. Nathan is assumed to flout the maxim of quality because he has said something that is blatantly wrong and lacks adequate evidence. He knows that Lou has no experience in nursing people with quadriplegia yet he states that Will is in good hands, either as a lie or an ironic statement.

In translating the utterance in bold, the translator applied the reduction technique: the word "capable" in the target text has been omitted entirely.

\section{Generalization}

This technique is used to translate terms in the source text into more general or neutral terms in the target text. Here is one of the situations in which the translator applied this technique:

\section{Source text}

Patrick:

So you do think he's good looking?

Lou:

I can't believe you're doing this. I can't believe you're jealous of him. I'm not jealous of him.

Patrick:

How could I be jealous of a cripple? (Moyes, 2012, p. 132).

\section{Target text}

Patrick:

Jadi kau memang menganggap dia tampan?

Lou:

Aku heran kau melakukan ini. Yang benar saja, masa kau cemburu padanya.

\section{Patrick:}

Aku cemburu padanya. Mana mungkin aku cemburu pada orang cacat? (Moyes, 2016, p. 318).

Patrick talks about Lou's profession as a caretaker for Will. He thinks Lou makes Will her first priority, and Lou takes it as jealousy. However, Patrick denies it with a rhetorical question, saying there is no way that he would be jealous of Will. In this situation, Patrick implies that Will is nothing compared to himself, for he is a healthy young athlete and of course, a normal man.

The word "cripple" is a slur that indicates someone whose body is so damaged that they can no longer walk. Instead of translating the term with "pincang", which is more explicit, the translator decided to apply the generalization technique by generalizing the term with "orang cacat". It refers to the actual condition of the main character who is handicapped.

\section{Literal Translation}

Literal translation is the technique which translates a word or an expression word for word. This translation occurs when there is exact structural, lexical, even morphological equivalence between two languages. This only possible when the two languages are very close. That is why sometimes it works and sometimes does not. 


\section{Source text}

Will:

So there are no carrots on that?

Lou:

Well... okay ... um... I suppose I thought vegetables would be good for you?

Will:

Let me get this straight. You think a teaspoon of carrot would improve my quality of life? (Moyes, 2012:50).

\section{Target text}

Will:

Jadi, makanan itu tidak ada wortelnya?

Lou:

Yah... Oke... Em... Kupikir sayuran bagus untukmu.

Will:

Kutegaskan ya. Kau pikir satu sendok teh wortel bisa memperbaiki kualitas hidupku? (Moyes, 2016, p. 109).

It is lunchtime. Lou prepares the meal, which is roast beef with mashed potato. Mrs. Traynor tells Lou to put some vegetables on the plate, even though Will does not want it. Will catches this and is displeased.

In the conversation, the translator employed literal translation technique in rendering the phrase "a teaspoon of carrot" as "satu sendok teh wortel". In Indonesian, the term "satu sendok teh" is not commonly used to quantify vegetables. On the contrary, the term which is more generally used is "sepotong" as in "sepotong wortel".

\section{Variation}

Variation is a technique where the translator changes linguistic or paralinguistic elements (intonation, gestures) that affect aspects of linguistic variation; changes in textual tone, style, social dialect, geographical dialect, etc.

\section{Source text}

Will:

No.

Nathan:

That looks like something my mum would wear.
Will:

You never told me your mum was Nana

Mouskouri. (Moyes, 2012, p. 117).

\section{Target text}

Will:

Tidak.

\section{Nathan:}

Kelihatannya kayak jenis baju yang akan dipakai ibuku.

\section{Will:}

Kau tidak pernah bilang bahwa ibumu adalah Nana Mouskouri.(Moyes, 2016, p. 277).

Lou asks Will his opinion of the dress she will wear to the concert. She enters the living room to show it to Will. Apparently, Will does not like the first dress. Nathan, who is there too, gives his opinion sarcastically by saying that Lou dresses like his mother, and Will suggests that it is in the style of Nana Mouskouri, an old Greek singer. Here, Nathan and Will imply that the dress is out of date. Therefore, their utterances can be found to be flouting the maxim of quality.

The translator applied the variation technique in translating the verb "told" into an informal term in the target language, which is "bilang". The formal forms of the word in the target language, according to Kamus Besar Bahasa Indonesia (KBBI) are "memberitahu”, mengatakan", or "menceritakan".

\section{Discursive Creation}

Discursive creation is a type of translation technique which establishes a temporary equivalence that is totally unpredictable out of context.

\section{Source text}

Nathan:

I think we're going to need some help. I can't even get the chair back on to the path. It's stuck. I could lift you into the front seat, Will, if I tilt it back a little. And then Louisa and I could see if we could get the chair in afterward.

Will:

I am not ending today with a fireman's lift. (Moyes, 2012, p. 109).

Nathan:

Sorry, mate. But Lou and I are not going to 
manage this alone. Here, Lou, you're prettier than I am. Go and collar a few extra pairs of arms, will you?

\section{Target text}

Nathan:

Kurasa kita butuh sedikit bantuan. Aku bahkan tidak bisa mendorong kursi ini ke jalan setapak lagi. Tersangkut di sini. Aku bisa mengangkatmu ke tempat duduk depan, Will, kalau kursi ini kujungkitkan sedikit ke belakang. Setelah itu Lousia dan aku akan mencari jalan untuk memasukkan kursinya.

\section{Will:}

Aku tidak mau digendong masuk ke mobil. (Moyes, 2016, p. 257).

\section{Nathan:}

Maaf, mate, tapi Lou dan aku tidak akan bisa menngani berdua saja. Hei, Lou, kau kan lebih cantik daripada aku. Cobalah pergi mencari bala bantuan sedikit, oke?

On the way to the racecourse, Will's chair is stuck in the mud. Nathan and Lou decide to seek help in order to get Will and his chair back on the path. Will does not like the idea of asking other people to lift him up. Will is regarded to flout the maxim of quality by exaggerating the statement. He picks the image of a fireman's lift because it is a humiliating way to be carried,

The translator used discursive creation in translating the phrase "a fireman's lift". The term could be translated into "bantuan petugas damkar", however, the translator decided to use a temporary equivalence which downgrades the level of exaggeration in the statement.

\section{Particularization}

This technique uses a more particular or concrete term in the target language as the equivalence of a word or term which is general in meaning. It is the opposite to the generalization technique.

\section{Source text}

Will:

Interesting choice of footwear. (Moyes, 2012, p. 72). You know you don't dress like someone from around here. I quite look forward to seeing what insane combination you're going to turn up in next.
Lou:

So how should "someone round here" dress?

\section{Target text}

Will:

Pilihan sepatumu cukup menarik. (Moyes, 2016, p. 164). Tahu tidak, gaya berpakaianmu tidak seperti orang local. Aku selalu penasaran, kombinasi edan apa lagi yang akan kau pakai berikutnya.

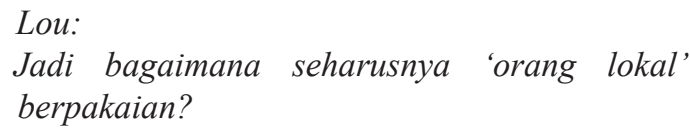

Mrs. Traynor comes out to tell Will and Lou that the cleaners would need 25 more minutes to finish their work. Lou takes Will out for a slow stroll around the garden. Will attempts small talk by giving his opinion on Lou's shoes, a pair of shoes that made Patrick think she looked like a leprechaun dragqueen. His statement is regarded as flouting the maxim of quality as it is known to be false. Will does not really think that the shoes are interesting but rather that they look peculiar.

The word "footwear" has a general meaning as outer coverings for feet. However, the translator used the particularization technique in translating the word into "sepatu" (shoes), which is a more specific term in the target language.

\section{Description}

Description is a technique that replaces the term or expression with a description of its form and/ or function. Here is one of the examples of the description technique found in this study:

\section{Source text}

Will:

You look like you're about to serve the ice creams.

Nathan:

Aw, mate, but you'd make a great maid. Feel free to wear that one in the daytime. You'll be asking her to dust the skirting next. (Moyes, 2012, p.117).

\section{Target text}

Will:

Kau seperti akan menyajikan es krim. 
Nathan:

Aw, mate kau bisa menjadi pelayan yang keren. Silakan memakai baju itu siang hari. Berikutnya kau akan menyuruh dia membersihkan kavu pelapis tembok. (Moyes, 2016, p. 117).

Will and Lou are about to go to a concert. Lou asks Will what would be best to wear. The outfit she wears is a very severe black dress, cut on the bias and stitched with white collar and cuffs. Will thinks that Lou looks like an usher who is ready to serve some ice cream to the customers. Nathan on the other hand, says that Lou looks like a maid, so much that he thinks Will would ask her to dust the skirting wearing the dress. The statement is understood to be false, as Will will not ask Lou to dust the skirting in that dress. He just wants to make fun of her. Here, Nathan wants to indicate that the old black dress is not appropriate for a concert. Therefore, Nathan is presumed to flout the maxim of quality.

Here, the translator decided to translate the term "skirting" by giving a brief description of its function. It helps the readers to simply understand the word, so that it is not necessary to re-read the text

\section{Translation Quality}

\section{Accuracy}

Accuracy is a term used to evaluate the translation. It is meant to indicate an equivalence between the two texts. The concept of equivalence refers to the similarity of content in both texts (Nababan et al., 2012). In this study, the accuracy assessment of the utterances that flout the maxim of quality is separated into three categories: accurate (116 pieces of data), less accurate (21 pieces of data), and inaccurate (2 pieces of data). It can be concluded that the average score of translation accuracy, on a scale of 1 to 3 , is 2.87. The distribution of findings related to translation accuracy is presented in the following figure:

Figure 1. Translation Accuracy

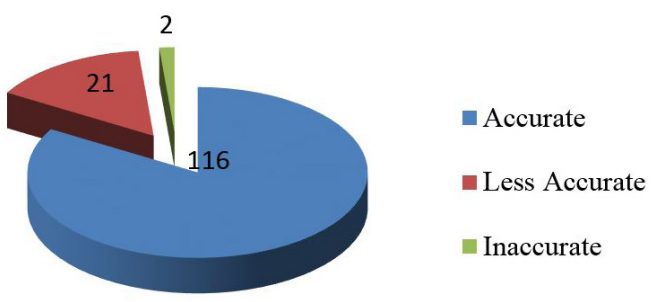

\section{Accurate}

Based on the assessment conducted through focus group discussion, it was found that there are 116 pieces of data $(84.45 \%)$ belonging to this category. The data classified as accurate are those where the content in the source text is accurately and clearly transmitted into the target text without any distortion of meaning (Nababan, 2012). The accurate translation is scored at 3 in the assessment.

\section{Source text}

Nathan:

He is in a good mood.

Lou:

Is he?

Nathan:

He says you're trying to poison him. (Moyes, 2012, p. 50).

Lou:

Yes... Well... Give me time.

\section{Target text}

Nathan:

Suasana hatinya sedang bagus.

Lou:

Oya?

Nathan:

Dia bilang kau mencoba meracuninya. (Moyes, 2016, p. 111).

Lou:

Yah... well... memang perlu waktu.

In the conversation above, Lou is making a cup of tea for Will in the kitchen. Nathan walks in and tells Lou that Will is in a good mood. He says that Will has said that Lou was trying to poison him. What Will meant by poison him is that Lou sneaked a piece of carrot into his lunch. The statement is counted as flouting the maxim of quality, as it lacks adequate evidence. In the reality, Will was just pretending to be mad at Lou for feeding him healthy food. The data is scored as accurate, as the meaning in the source text is properly transferred into the target text. The translator mostly used established equivalent in translating the text. 


\section{Source text}

Will:

You are insane!

Your whole family is insane.

Lou:

But it worked.

Will:

And $^{1}$ you're a God-Awful singer ${ }^{2}$. I hope your dad was better ${ }^{3}$. (Moyes, 2012, p. 64).

\section{Target text}

Will:

Kau memang sinting!

Seluruh keluargamu edan.

Lou:

Tapi berhasil, kan.

Will:

Dan'l suaramu jelek sekali ${ }^{2}$.

Mudah-mudahan suara ayahmu lebih bagus ${ }^{3}$. (Moyes, 2016, p. 145).

Lou has sung the Molahonkey song, the song her dad used to sing when she had a nightmare. The song sounds ridiculous and Will says that Lou is a God-awful singer. He hopes that her father has a better voice. By saying that, Will flouts the maxim of quality. He does not genuinely care about her father's voice.

The translator used 3 translation techniques in translating the utterance: established equivalent ${ }^{1}$, modulation $^{2}$, and transposition ${ }^{3}$. Those techniques did not affect the accuracy of the translation. The information in the source text is perfectly transferred into the target language. There is no distortion in meaning. Even though the use of modulation technique changed the semantics meaning and shifted the point of view in the source text, both texts conveyed the same idea.

\section{Less Accurate}

There are 21 items of data (15.11\%) categorized as less accurate. This data is considered less accurate if the content in the source text is conveyed less appropriately to the target text. It could be caused by distortions, ambiguities, and deletions of meaning (Nababan, 2012). Less accurate translation is scored at 2 in the assessment. In this study, less accurate translations are caused by the application of the reduction technique, addition technique, and literal translation technique.

Less accurate translation caused by the application of the literal translation technique:

\section{Source text}

Lou:

So glad that you are so flexible.

I'll certainly recommend you to everyone I know. (Moyes, 2012, p. 108).

Will:

Louisa!

\section{Target text}

Lou:

Senang sekali dengan sikapmu yang fleksibel. Aku akan merekomendasikan pada semua orang yang kukenal. (Moyes, 2016, p. 254).

Will:

Louisa!

Lou gives compliments to the receptionist who did not let them eat in the restaurant because it is only available for special badge holders. The statements are identified as flouting the maxim of quality because Lou does not mean to commend the receptionist. In fact, what she tries to imply is the contrary.

The data is classified as less accurate, as the information in the source text not perfectly transferred into the target text. There are some omissions of words "so" and "certainly". The translator used the reduction technique in translating the utterances. This can be seen from the fact that the word "so" in statement 1 and "certainly" in statement 2 were omitted. The omissions affect the translation accuracy because the message is not perfectly transferred. Therefore, the piece of data is classified as a less accurate translation.

Less accurate translation is caused by the application of the addition technique:

\section{Source text}

Mrs. Traynor :

You could've rung. I must have called or texted you both eighteen times. It was only when I managed to call the Dewars' house and somebody told me "the man in the wheelchair" had gone to a hotel that I could be sure you hadn't both had some terrible accident on the 
motorway.

Will:

"The man in the wheelchair."

Nice. (Moyes, 2012, p. 190).

\section{Target text}

Mrs. Traynor:

Kalian kan bisa menelepon dulu. Aku pasti sudah menelpon atau mengirim SMS sekitar delapan belas kali kepada kalian berdua. Setelah akhirnya aku berhasil menghubungi rumah keluarga Dewar dan seseorang bilang padaku bahwa 'laki-laki di kursi roda' itu sudah pergi ke hotel, barulah aku yakin kalian tidak mengalami kecelakaan parah di jalan.

Will:

"Laki-laki di kursi roda."

Bagus sekali. (Moyes, 2016, p. 472).

Will and Lou finally get back a day after Alice's Wedding. Mrs. Traynor is so mad that she unintentionally says there was a man who identified him as the man in the wheelchair. Will's words make him seem not bothered like he treats it as a joke. In this situation, Will actually flouts the maxim of quality by saying something that is not true. He actually is offended by people who identify him as a disabled man.

The utterance belongs to the category of less accurate translation due to the emergence of additional information which does not exist in the source text. The word "nice" is translated using the addition technique. The use of addition technique has caused the imbalance of the information between the source and the target text.

Less accurate translation is caused by the application of the literal technique:

\section{Source text}

Bernard:

Mav this be the year our Lou finally grows up. (Moyes, 2012, p. 127).

\section{Target text}

Bernard:

Mungkin tahun ini Lou kami akhirnya tumbuh dewasa. (Moyes, 2016, p. 304).
In the conversation above, Bernard is making a wish on Lou's birthday. Through the utterance, Bernard actually implies that Lou should make an improvement in her life, considering she has not done much yet and she is already 27 years old.

The translator applied the literal translation technique in translating the word "may", which essentially indicates that somebody wishes for something very strongly. However, the expression is out of context, and converted into a general statement. The use of this technique affects the translation accuracy since the meaning that the author intends to deliver is not thoroughly transmitted in the target text. As a consequence, the translation is categorized as less accurate.

\section{Inaccurate}

A text is categorized as inaccurate if the meaning in the source text is inaccurately transferred or omitted in the target text. There are only 2 occasions $(1.44 \%)$ where it was considered to be inaccurate. They are scored as 1 in the assessment. The inaccurate translations in this study were both examples of the use of the discursive creation technique. It can be seen as follows:

\section{Source text}

Will:

Here, Clark. Do me a favor?

Lou:

What?

Will:

Scratch my ear for me, will you? It's driving me nuts. (Moyes, 2012, p. 74).

Lou:

If I do, you'll let me cut your hair? Just a bit of a trim?

\section{Target text}

Will:

Hei, Clark. Mau tolong aku?

Lou:

Apa?

Will:

Garukkan telingaku. Gatal sekali. (Moyes, 2016, p. 168).

Lou: 
Kalau kugarukkan, kau akan membolehkan aku menggunting rambutmu? Dirapikan sedikit saja.

Will asks Lou to scratch his ear. He says it is so itchy that it drives him crazy. By uttering such a statement, Will is counted as flouting the maxim of quality. He exaggerates the statement and makes it as if the itchy ear could lead to insanity.

The translation is classified to be inaccurate because "it's driving me nuts" is an idiomatic expression used to show annoyance or discomfort at something extremely disturbing. The translator has failed to catch the expression and she used discursive creation to translate the text. It is a very different form of meaning to that in the source text. It affects the translation accuracy since the meaning in the source text is not completely transferred, therefore it is classified as inaccurate translation.

\section{Acceptability}

Translation equivalence covers two characteristics, i.e. "equivalent" which refers to the source language (SL) message, and "natural", which refers to the receptor language. Nida explains that "natural" signifies three areas of communication process: a natural rendering should fit the whole receptor language and culture, the context of the specific message, and the receptor language audience (Nida, 1964). There are only two categories of translation acceptability in this study: acceptable (131 items of data) and less acceptable (8 data). The average score of translation acceptability is 2.93. The distribution of findings related to translation acceptability is displayed in the following figure:

Figure 2. Translation Acceptability

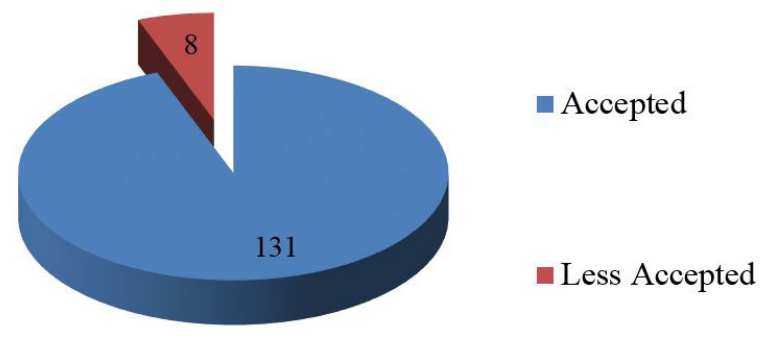

\section{Acceptable}

There are 131 pieces of data $(94.24 \%)$ classified as accepted, where the translation is natural, the cultural aspects for example e.g. the choices of word or diction are familiar to the reader and the structure of the phrases, clauses or sentence are suitable to the principles in the target language. The data categorized as acceptable can be seen as follows:

\section{Source text}

Lou:

Right. We've made it. Now for the fun bit. (Moyes, 2012, p. 104).

\section{Target text \\ Lou: \\ Nah. Kita berhasil. Sekarang bagian yang asyiknya. (Moyes, 2016, p. 243).}

Lou and Nathan worry about Will's chair which is going to sink because of the soft ground. They have to drag the chair towards the path. When they have finally made it to the pathway, Lou realizes that there is only one entrance, a turnstile. Lou speaks as if it is something more fun than just dragging Will with his chair out of the muddy path.

The bold sentence is regarded to flout the maxim of quality, as it does not correspond to reality. She knows that they cannot get Will over the turnstile and at the end, they have to walk for 200 yards to get to the disabled entrance. Even Lou is almost fainting by the time they get in.

In the statement above, the translator has applied the established equivalent technique in translating the utterances. The terms in the source text are understandable and acceptable in the target language. There is no irregular word or term which could result in an indistinct meaning.

\section{Less Acceptable}

Translation is categorized as less accurate when the translation is natural, but there is still a slight confusion in the use of certain terms or there is a minor grammatical error. There are 8 pieces of data $(5.76 \%)$ that are classified as less acceptable. The less acceptable translation is the result of the employment of the pure borrowing and literal translation technique. Some of the examples are shown below.

In this study, the use of pure borrowing is not thoroughly appropriate. The application of this technique could affect readers' understanding in interpreting certain terms.

Less acceptable translation is caused by the application of the pure borrowing technique: 


\section{Source text}

Alice:

Are we still going away this weekend?

Will:

Depends on what happens on this deal. It's a bit up in the air at the moment. There's still a possibility I might have to be in New York. Nice dinner somewhere Thursday, either way? Your choice of restaurant.

Alice:

Dinner. With or without Mr. BlackBerry?

Will:

What?

Alice:

Mr. BlackBerry makes me feel like Miss Gooseberry. (Moyes, 2012, p. 7).

\section{Target text}

Alice:

Akhir minggu ini kita jadi pergi?

Will:

Tergantung perkembangan. Saat ini urusannya agak menggantung. Masih ada kemungkinan aku harus berangkat ke New York. Pokoknya kita makan malam yang enak hari Kamis? Kau yang pilih restorannya.

Alice:

Makan malam. Dengan atau tanpa $\mathrm{Mr}$ BlackBerry?

Will:

Apa?

Alice:

Mr. BlackBerry membuatku merasa seperti Miss Gooseberry. (Moyes, 2016, p. 9).

Will is always busy at work and has no time to stay with Alice for the weekend. Will asks her out for a fine dinner on Thursday evening. Alicia wants to make sure that there will be no disruption from work. From the statement, Alicia flouts the maxim of quality by calling herself "miss Gooseberry" (a person who will tag along with a couple or a few couples, when they themselves are single), while in reality, she is the one and only girlfriend of Will.

The translator chose the pure borrowing technique in translating the terms "Mr. BlackBerry" and "Miss Gooseberry", taking the words straight from the source text. The translator used pure borrowing in order to retain some "feel" of the source language. However, the translation is categorized as less acceptable, as the use of "Gooseberry" to refer to a person who will tag along to a couple is an idiom that exists in English but not in Indonesian. Indonesian readers may interpret it differently due to different background knowledge.

Less acceptable translation is caused by the application of the literal technique:

\section{Source text}

Will:

Well?

Lou:

I'm not sure I like seeing this much of your face. It's a bit unnerving. (Moyes, 2012, p. 75).

\section{Target text}

Will:

Bagaimana?

Lou:

Rasanya aku tidak begitu senang melihat tampangmu sebanyak ini. Agak bikin gugup. (Moyes, 2016, p. 172).

Lou sets out to cut Will's hair and shave his beard. She sneaks round in front of him to see how he looked. Surprisingly, she likes the new look but hesitates to tell the truth. However, Will knows exactly that Lou loves his new look so much because she is blushing. Therefore, Lou is found to flout the maxim of quality by not telling the truth.

The phrase "this much" here refers to the amount of his face she can see, however, the translator has applied the literal translation technique and disregarded the context of the conversation. Consequently, the translation is not acceptable in the target language for it is ambiguous. It could mean Will has more than one face.

In this quality assessment, most of the translations are categorized as accurate and acceptable. Established equivalent appears to be the most dominant technique used to translate the utterances. This technique is able to maintain the transmission of information according to the context. It does not change the focus of the text. It results in 116 utterances 
that have a high level of accuracy. Furthermore, this technique is able to deliver the meaning in the source text by way of using common terms in everyday conversation. Thus, this technique also contributes to a high level of acceptability in 131 utterances. The use of other translation techniques does not significantly affect translation quality. However, the use of particular translation techniques was found to have negative effects. Reduction makes the translation lose its equality by reducing one or more pieces of information in the source text. Addition, by contrary, appends certain information which does not exist in the source text. Both techniques create translations that were judged to be less accurate (scored as 2). Further, discursive creation causes a translation discrepancy. It establishes a temporary equivalence that is totally unpredictable out of context. This technique makes translations judged to be inaccurate (scored as 1) because the target text expresses a different message. In terms of acceptability, pure borrowing and literal translation are identified as giving negative effects. Those techniques cause the translation to be judged as less acceptable (scored as 2). The translator used pure borrowing in translating terms such as Miss Gooseberry, Quad $r$ Us and badge. As Indonesian language readers share different background knowledge compared to speakers of the source language, those terms are viewed to be unfamiliar and could lead to misperception. The application of the literal technique, meanwhile, generates offcontext translation resulting in certain terms sounding unnatural.

\section{CONCLUSION}

Translation techniques are used to describe how the result of translation functions related to the corresponding units in the source text (Molina \& Albir, 2002). Therefore, this paper has tried to describe how translation techniques may affect the translation quality in terms of its accuracy and its acceptability. As seen from the findings and discussion, there are 139 utterances that flout the maxim of quality in Jojo Moyes' Me Before You. The Indonesian translator, Tanti Lesmana, approached these by applying different translation techniques. According to the assessment attained from the raters, it can be concluded that the final score of translation quality in terms of accuracy is 2.82 while the score of translation acceptability is 2.93 (on a scale of 1 to 3 ). It means that the translation of the utterances that flout the maxim of quality in $\mathrm{Me}$
Before You can be categorized as a fair translation. Established equivalent comes up as the most frequently used technique that has the capability to convey a close meaning in the target text and produces a high level of translation accuracy and acceptability. However, the application of translation techniques such as reduction, addition, and discursive creation are responsible for low scores in translation accuracy, while pure borrowing and literal translation are responsible for low scores in translation acceptability.

Based on the conclusion made above, it is hoped that the findings of this study can facilitate translators to be more informed of the various translation techniques which could be used in translating utterances that flout the maxim of quality (implicatures) in order to produce a qualified outcome. In addition, translators are urged to give more attention to the context of the utterances. In doing so, translators will be able to translate utterances based on what the author intends to communicate. It can also minimize the occurrence of a meaning shift between the two languages. Further, this is a product-oriented study. The findings in this study are phenomena that exist in the text of this specific translation. Therefore, the writer suggests that similar research could be done by focusing more on the translation process, so that the justifications and other issues related to translators' decision-making could be revealed.

\section{REFERENCES}

Abdeelah, A. S. (2004). The translators dilemma Implicatures and the role of the translator. Translation Journal, 8(2), 54-63.

Akhiroh, N. S. (2013). The influence of translation technique on the quality of the translation of international news in Seputar Indonesia daily. Language Circle Journal of Language and Literature, 7(2), 41-51.

Black, E. (2006). Pragmatic Stylistic. Edinburgh: Edinburgh University Press Ltd.

Brown, P., \& Stephen, L. (1987). Politeness: Some universals in language usage. Cambridge: Basil Blackwell.

Cutting, J. (2002). Pragmatics and discourse: A resource for students. New York: Routledge.

Grice, H. P. (1975). Logic and conversation. New York: Oxford University Press.

Hatim, B., \& Jeremy, M. (2004). Translation: An advanced resource book. UK: Psychology Press.

Larson, M. L. (1984). Meaning-based translation: A Guide to cross-language Equivalence. New York: 
University Press of America.

Molina, L., \& Albir, A. (2002). 'Translation techniques revisited: A dynamic and functionalist approach'. Meta: Translators' Journal, 47(4), 499-512.

Moyes, J. (2012). Me before you, [PDF]. https:// bookwormbyheart.blogspot.co.id/2016/03/ jojo-moyes-book-collection-kindle-epub.html, accessed on November 172016.

Moyes, J. (2016). Me Before You. (translated from English into Indonesian by Lesmana, T. Sebelum mengenalmu). Jakarta: PT Gramedia Pustaka Utama.

Nababan, M. R. (2003). Teori menerjemah bahasa inggris. Yogyakarta: Pustaka Pelajar.

Nababan, M. R., Nuraeni, A., \& Sumardiono. (2012). 'Pengembangan model penilaian kualitas terjemahan'. Kajian linguistik dan sastra, 24(1), 39-57.

Newmark, P. (1988). A textbook of translation. London: Prentice Hall.

Nida, E. A. (1964). Towards a Science of Translating. Leiden: E. J. Brill.

Nugraha, S. K. (2016). Kajian terjemahan kalimat yang merepresentasikan tuturan pelanggaran maksim pada subtitle film 'The Queen' (Kajian terjemahan dengan pendekatan pragmatik). Thesis. Sebelas Maret University: Surakarta.
Nuraeni, Ardiana., Kusumawati, F., \& Nababan, M. R. (2016). A Translation Study on School Signboards in Surakarta: Types, Functions, and Quality. Humaniora, 28(2), 198-207.

Paltridge, B. (2006). Discourse Analysis. London: MPG Books Ltd.

Putri, R. (2016). Terjemahan turn yang mengakomodasi flouting maksim prinsip kerjasama dalam novel The Cairo Affair karya Olen Steinhauer. Thesis. Sebelas Maret University: Surakarta.

Sudaryanto. (1986). Metodologi penelitian linguistik, ke arah memahami metode linguistik. Yogyakarta: Gajah Mada University Press.

Sumardiono. (2012). Kajian terjemahan ujaran yang menagandung implikatur pada novel The Da Vinci Code (Sebuah tinjauan pragmatik pada penerjemahan). Thesis. Sebelas Maret University: Surakarta.

Spradley, J. P. (1980). Participant observation. New York: Holt, Reiinheart and Wiinson.

Thomas, J. (1995). Meaning in Interaction: an Introduction to Pragmatics. England: Longman.

Wijana, I. D. P., \& Muhammad, R. (2011). Analisis wacana pragmatik: kajian teori dan analisis. Surakarta: Yuma Pressindo.

Zhonggang, S. (2006). A Relevance Theory Perspective on Translating the Implicit Information in Literary Texts. Journal of Translation, 2(2), 41-60. 